\title{
Financial Life Skills of Finnish College Students: A Pilot Study on Credit Cards and Budgets
}

\author{
Marty Ludlum \\ University of Central Oklahoma \\ Linn Hongell \\ Arcada University of Applied Science \\ Christa Tigerstedt \\ Arcada University of Applied Science \\ Burle Steelman \\ University of Central Oklahoma \\ Cenea Reese \\ University of Central Oklahoma
}

Are Finnish students prepared for the realities of the economic world? Will Finnish college students be buried under student loans and credit card debt? We surveyed Finnish college students $(n=135)$ in the spring of 2016. We examined their use of student loans, credit cards, budgeting, and gambling. We found student loans were modestly used, gambling was almost nonexistent, and budgets were underutilized. However, we found Finnish students to be uninformed about financial tools such as credit cards. We conclude with discussing how to move into new subject areas with this pilot project.

Keywords: Financial Skills, College Student, Survey, Debt, Student Loans

\section{INTRODUCTION}

Financial literacy has been defined as "the ability to make informed judgments and to take effective actions regarding the current and future use and management of money" (U.S. Dept. of Treasury, 2008). Often financial literacy is defined in academic circles as earnings ratios, investment risks, and compound interest. We wanted to take the topic in another direction. To avoid confusion, we will describe our concept as financial life skills instead of financial literacy. Few of our students will become hedge fund managers, but all of them will become consumers. What financial life skills does a consumer need in the modern economy? 
Financial life skills has two broad issues to the campus community: leaving college high in debt (student loans and credit cards) and leaving college without understanding financial instruments for day to day life (responsible use of credit, making a budget, and avoiding financial pitfalls, such as gambling).

In America, credit cards on campus have been a catastrophe. Easy credit is everywhere. Norvilitis et al. (2006) found that 74\% of U.S. students had at least one credit card. Robb \& Sharpe (2009) found 66\% of Midwest students had at least one credit card. Fifty percent $(50 \%)$ of college students have four or more credit cards (Block, 2009). Students are using credit cards. By 2010, the average college student credit card debt soared to $\$ 10,000$ (Hodson \& Dwyer, 2014). When student loans and credit cards were combined, the average debt for an American college graduate is \$20,400 (Nellie Mae, 2007).

The use of credit is not necessarily bad if the user is making an informed choice. This is not the case. American students do not understand credit cards and are financially harmed from this lack of knowledge. Financial illiteracy is very expensive. Penalty fees generate \$20 billion for credit card issuers (Chu, 2009a). Retroactive interest rate changes and penalty interest rates cost consumers $\$ 10$ billion a year (Samuelson, 2010).

Is this problem unique to America? This is a pilot study to combine several aspects of financial life skills (student loans, budgets, and credit cards) in single project for Finland. We wanted to see a more comprehensive view of Finland's college students and their understanding of key, real world monetary issues. The current project examined an understudied population, higher education (university of applied science) students in Finland.

\section{REVIEW OF THE LITERATURE}

Previous studies on Finland's business students are sparse, because of the small population. Finland's current population is around 5.5 million people (Statistics Finland, 2018). The current project adds to the knowledge of the discipline by examining the financial life skills of this distinct group of future business leaders.

Culturally, Finland is nearly homogeneous (Niemi, Kuusisto, and Kallioniemi, 2014). Previously, Finland had a history as a "closed society" after World War II, allowing little immigration (Koivukangas, 2005). However, this has been changing in the past decade. In Finland, one of the strong socialization forces is the Lutheran Church, which historically was monolithic, and still accounts for $77 \%$ of the population (Vogelaar, 2013). However, this too has been changing during the past 10 years. Finland has become more diverse, even if their immigration policy is among the strictest.

Higher education has a long history in Finland. Their first university was founded in Turku in 1640 (Clarke, 2005). Currently, Finland's higher education system is large, with 14 universities and 23 universities of applied science [UAS]. The mission of universities is to conduct scientific research and provide instruction and postgraduate education based on this research. The universities of applied sciences on the other hand are supposed to train professionals to meet labour market needs and work on R\&D which supports instruction and strengthens regional development in particular.

Finland moved from a student loan based system to a grant-based system of higher education in the 1990s (Kivinen \& Hedman, 2000; and Asplund, Abdelkarim, \& Skalli, 2009). Finland has no tuition or fees for citizens and permanent residents (Clarke, 2005). Because of the grant based system, cost of education is not an issue, so admission into higher education has become very competitive. The number of university students has rapidly increased since going to a grant based system (Kivinen \& Hedman, 2000). Tuition is not the only savings for Finland's students. Materials for the course (books, etc.) may be provided free for the student (Kivinen \& Hedman, 2000).

The literature on Finnish students and financial life skills has been sparse. A few findings have emerged. Independent students (not living with parents) are more likely to take out student loans in Finland (Kivinen \& Hedman, 2000). In three-decade study, researchers found Finnish college students allocate $50 \%$ of their income for housing and food (Lahtinen, 1993). Because of low out-of-pocket costs for higher education, students have more disposable income. 
Student loans have a different structure in Finland. Students' loans are near market rates, and are negotiated between the student and the bank (Asplund, Abdelkarim, and Skalli, 2009). However, Finnish students have not focused on the details of their loans. Distressingly, Purhonen (1995) found that 25\% of Finnish students who got loans did not know the interest rate or the maturity date of their loans.

In contrast, American college students have been examined in detail, and most of the findings are discouraging. American college students had low level of knowledge on credit card details, such as interest rates, credit limits, or credit fees (Jones, 2005; Warwick and Mansfield, 2000). Since the interest rate is the primary cost of credit, a financially literate student should know the interest rate he/she is paying (Robb and Sharpe, 2009). College students did not possess a strong financial knowledge (Ludlum and Smith, 2010; Jones, 2005; Warwick and Mansfield, 2000; Chen and Volpe, 2002). This lack of knowledge covered not only credit use, but essential functioning like budgeting and retirement planning (Norvilitis et al. 2006).

Ludlum, et al., (2012) surveyed American college students and found that $70 \%$ of undergraduate college students had a credit card. However, only $9.4 \%$ of students paid their credit card in full each month. This leaves over $90 \%$ of students paying high interest charges. Only $14.6 \%$ of students claimed to know the interest rate they paid on credit. Fewer than $10 \%$ knew their interest rate, the late charges, and the over balance penalty on the credit cards they use. This demonstrated less than one in ten knew basic facts of a financial tool they have in their pocket every day.

\section{METHOD FOR THE SURVEY}

A convenience sample was taken from large business survey classes at Arcada University of Applied Sciences in Helsinki, Finland in the spring of 2016. Arcada is public and has over 2,700 students and over 200 faculty and staff (Arcada, 2018). The survey was conducted in English. The students at Arcada are multilingual (Finnish, Swedish, and English), with several programs taught in English.

Finland has a long history of being a multilingual country, being part of Sweden from 1809-1917 (Clarke, 2005; and Anckar, 2000). In 1917, Finland became independent with two official languages (Anckar, 2000). Some colleges such as Arcada also teach classes in English to benefit their international student exchange programs (Anckar, 2000).

Students completed the IRB approved questionnaire during class time. The survey instrument was voluntary and anonymous. We were best able to minimize the socially appropriate response bias by using a large group survey, with anonymous results and confidential submissions. The instructor was not part of the survey collection to avoid undue influence. A total of 135 surveys resulted. However, some questions had fewer than 135 responses. The text of the questions is in the appendix.

Most (96\%) of the participants were business majors. Business is one of the most popular disciplines for Finnish undergraduate education (Ahola \& Kokko, 2001). The respondents were in the following academic years: first, $72 \%$; second, $17 \%$; third, $8 \%$; and fourth, $3 \%$. In our sample, females outnumbered males 56\% to 44\%. Previous studies found Finnish college students were over $75 \%$ female (Jauhiainen, et al, 2007; Kivinen \& Hedman, 2000). The group consisted of primarily traditional students with an average age of 21.93 years. Only four percent of the respondents were married, and only four students had children. This contradicts prior research that found a significant number $(33 \%)$ of Finnish college students were married (Jauhiainen, et al 2007). Most students worked while attending school (70\%). Prior studies found that the majority (57\%) of Finnish college students were employed (Jauhiainen, et al, 2007, and Ludlum, Hongell, \& Tigerstedt, 2013). Part time work while in college is common despite socioeconomic background (Asplund, Abdelkarim, and Skalli, 2009). This is consistent with prior research (Ludlum, Hongell, \& Tigerstedt, 2013).

Politically, the students were much divided; 38\% self-identified with the Swedish Party, 13\% identified with the National Coalition, and smaller factions identified with the five other main political parties in Finland, and 28\% identified as "other". In religion, Lutheran was the dominant group with $28 \%$, also Christian was $21 \%$, Catholic was $7 \%$, non-religious was $38.4 \%$, and all other faiths were smaller factions. Details are reported in Table 1. 
TABLE 1

DEMOGRAPHIC RESULTS

\begin{tabular}{|l|l|l|}
\hline 2016 sample & Raw data & Percentage \\
\hline Completed surveys & 135 & 100 \\
\hline & & \\
\hline Business majors & 110 & 95.65 \\
\hline Non-business majors & 5 & 4.35 \\
\hline & & \\
\hline Year in school & & \\
\hline First year & 94 & 71.76 \\
\hline Second year & 22 & 16.79 \\
\hline Third year & 11 & 8.40 \\
\hline Fourth year & 4 & 3.05 \\
\hline & & \\
\hline Males & 59 & 43.70 \\
\hline Females & 76 & 56.30 \\
\hline & & \\
\hline Religion & & \\
\hline Muslim & 1 & 0.78 \\
\hline Roman Catholic & 9 & 6.98 \\
\hline Christian & 27 & 20.93 \\
\hline Lutheran & 36 & 27.91 \\
\hline Hindu & 1 & 0.78 \\
\hline Buddhists & 5 & 3.88 \\
\hline Not religious & 50 & 38.76 \\
\hline & & \\
\hline Politics & & \\
\hline Centre Party & 4 & 3.51 \\
\hline Finns Party & 5 & 4.39 \\
\hline National Coalition & 15 & 13.16 \\
\hline Green League & 73.14 \\
\hline Socialist Democrat & & 6.14 \\
\hline Left Alliance & 0.88 \\
\hline Swedish Party & 37.72 \\
\hline Other & 28.07 \\
\hline & \\
\hline & & \\
\hline & & \\
\hline & & \\
\hline & & \\
\hline & & \\
\hline & & \\
\hline & & \\
\hline
\end{tabular}

\section{FINDINGS}

This pilot study examined several aspects of financial life skills in our sample: credit cards, student loans, as well as budgeting and gambling. We wanted to see a more comprehensive view of Finland's college students and their understanding of key, day-to-day consumer financial issues.

\section{Credit Cards}

In our sample of Finnish college students, having credit cards is fairly divided; $57 \%$ have credit cards, $42 \%$ do not. This finding is positive, with over $40 \%$ of students have avoided experimenting with credit. However, the positive results stop there. 
Of those students with credit cards, almost half (46.6\%) did not know his/her current balance. Additionally, a strong majority $(64.8 \%)$ of students with credit cards did not know the annual percentage rate for his/her credit card. Interestingly, only $8.45 \%$ of students thought their credit card interest rate was greater than ten percent.

A consumer should know more than the balance of his/her credit card and the interest rate. One of the major issues for consumers is the many fees attached to the easy use of credit. In our sample, $75.4 \%$ of students with credit cards did not know the fee for late payments, $90.7 \%$ of students with credit cards did not know the extra fee for getting a cash advance, and $81.8 \%$ of students with credit cards did not know the fee for being over their balance. These fees add great costs to the easy access to credit, and cost consumers millions of Euros each year. The results are disheartening. Finland's college students are lost in dealing with consumer credit.

\section{Student Loans}

When we examined student loans, the initial results were more positive: $64 \%$ of students in our example have no student loans. The strong majority of Finnish students have avoided the student loan crisis so common among American undergraduates. Further, Finnish students borrow less. For Finnish students with loans, $73 \%$ have less than 10,000 euros ( $\$ 11,700$ as of July, 2018) in loans. This amount represents half the student debt of American students. Only $26.7 \%$ of students with loans (10\% of students overall) have loans balances greater than 10,000 euros.

Finnish students with loans considered the loans a very short-term debt, often paying back the student loans before graduation. Only $36 \%$ of Finnish college students expected to have any student loan balance at graduation. A very small fraction (13.8\%) of Finland's students expect to take five years or more to pay off their loans.

Consumer protection for student borrowers is stronger in Finland. Interest rates for student loans are very low. Only three students in our sample reported paying more than two percent interest.

\section{Budgeting}

Budget issues were also a concern. A responsible consumer needs to budget their funds and expenses for sound financial planning. Our sample of college students were evenly divided: $51 \%$ report having a personal budget, $49 \%$ without a budget. However, it does not appear that Finnish students had a detailed budget. When we asked detailed questions about the budget, many students were not sure of basic budget details (housing and food) but students were very exact on cell phone costs. This budget item does seem to be a conscious concern for Finnish students.

\section{Gambling}

Student loans, credit cards, and budgets are not the only financial pitfalls. Gambling is another one. Casinos are new to Finland with the first established in 1994 (OnlineGambling.com, 2018). In Finland, gambling is state controlled by three entities: Veikkaus Ltd, Fintoto Ltd, and RAY (Karekallas, Raento, \& Renkonen, 2014). While casinos are sparse (fewer than five in the nation) Finland has a strong everyday gambling culture (Karekallas, Raento, \& Renkonen, 2014). Gaming machines are everywhere in Finland, resembling Nevada (Karekallas, Raento, \& Renkonen, 2014). Gambling is viewed differently in Finland. Since it is government run, the ties to illicit action or criminal behavior are not present. Also, the profits from gambling go to fund national interests in art, science, sports, youth work, etc., so many Finns consider gambling a "public good" (Karekallas, Raento, \& Renkonen, 2014).

In our sample, only $19(15.45 \%)$ of the students have visited a casino. Of the 19 students who visited a casino, none visited a casino more than twice a year. We were surprised by the low involvement in gambling of college students but found two compelling reasons. First, college students are always cashpoor. This fact seems to cross all cultures and nationalities. Second, college students should better understand the fleeting possibilities of winning at gambling, so less likely to participate.

We wanted to see if any demographic factors influenced the results in our pilot study. We crafted three research hypotheses. For each we started with a null hypothesis. Those hypotheses are: 
1. Gender (male/female) does not affect attitudes towards financial life skills;

2. Indoctrination (year in school) does not affect attitudes towards financial life skills; and

3. Religion (self-identified) does not affect attitudes towards financial life skills.

We ran chi square analyses for relationships for categorical dependent (has a credit card in own name and has a budget) and independent variables (gender, year in school, religion, and political affiliation). We ran regression analyses for the amount of student loan debt, the number of hours per week spent studying, the number of hours per week spent on the internet, and the number of hours per week spent reading. To maintain maximum consistency between the analyses, the same subset of the sample was used in each analysis.

Hypothesis 1: Gender (male/female) does not affect attitudes towards financial life skills. The results are detailed in Table 2 and confirm no difference in having a credit card in your name and gender and having a budget and gender.

TABLE 2

EFFECTS OF GENDER

\begin{tabular}{|l|c|c|c|}
\hline \multicolumn{1}{|c|}{ Question } & Chi-Square & df & p-value \\
\hline Credit card in your name & $\mathrm{x}^{2}=0.01$ & 1 & .92 \\
\hline Has a budget & $\mathrm{x}^{2}=0.002$ & 1 & .96 \\
\hline
\end{tabular}

Hypothesis 2: Indoctrination (year in school) does not affect attitudes towards financial life skills. The results indicate no differences in whether or not respondents had credit cards in their names or had a budget based on their year in school, and are detailed in Table 3 .

TABLE 3

RESULTS FOR INDOCTRINATION

\begin{tabular}{|l|c|c|c|}
\hline \multicolumn{1}{|c|}{ Question } & Chi-Square & df & p-value \\
\hline Credit card in your name & $\mathrm{x}^{2}=3.27$ & 3 & 0.35 \\
\hline Has a budget & $\mathrm{x}^{2}=2.73$ & 3 & 0.44 \\
\hline
\end{tabular}

Hypothesis 3: Religion does not affect attitudes towards financial life skills. The results reflect a lack of relationship between having a credit card in your name and having a budget and are shown in table 4.

TABLE 4

RESULTS FOR RELIGION

\begin{tabular}{|l|c|c|c|}
\hline \multicolumn{1}{|c|}{ Question } & Chi-Square & df & p-value \\
\hline Credit card in your name & $\mathrm{x}^{2}=5.48$ & 7 & 0.60 \\
\hline Has a budget & $\mathrm{x}^{2}=9.46$ & 7 & 0.22 \\
\hline
\end{tabular}

When we ran logistic regression for having a credit card in their name and for whether or not they have an established budget, neither model produced significant results. 
TABLE 5

REGRESSION RESULTS

\begin{tabular}{|c|c|c|}
\hline & Credit Card & Budget \\
\hline Gender & .10 & .08 \\
& $(.50)$ & $(.48)$ \\
\hline Year & .43 & -.02 \\
& $(.30)$ & $(.27)$ \\
\hline Religion & .06 & .08 \\
& $(.08)$ & $(.08)$ \\
\hline Political & -.09 & .05 \\
& $(.13)$ & $(.13)$ \\
\hline Employed & .55 & -.34 \\
& $(.42)$ & $(.41)$ \\
\hline Major & -1.35 & .23 \\
& $(1.70)$ & $(1.11)$ \\
\hline & Model n.s. & Model n.s. \\
\hline
\end{tabular}

We ran regression analysis on student loan debt, number of study hours per week, number of hours on the Internet per week, and number of hours reading by gender, year, religion, political affiliation, whether or not employed, and whether the respondent was a business major. The regression results for study hours per week were statistically significant $(p<.05)$, with business majors studying more than non-business majors, although in our sample, 75 of the 80 respondents were business majors.

TABLE 6

EXTENDED REGRESSION RESULTS

\begin{tabular}{|l|l|l|l|l|}
\hline & Student loan debt & Study hours/week & Internet hours/week & $\begin{array}{l}\text { Reading } \\
\text { hours/week }\end{array}$ \\
\hline Gender & -1173.46 & 1.14 & 4.41 & 1.28 \\
& $(2048.89)$ & $(1.72)$ & $(4.81)$ & $(2.21)$ \\
\hline Year & 1748.89 & -.29 & .86 & .63 \\
& $(1133.70)$ & $(.99)$ & $(2.66)$ & $(1.22)$ \\
\hline Religion & -181.16 & -.10 & $-1.64^{*}$ & -.11 \\
& $(327.68)$ & $(.28)$ & $(.79)$ & $(.36)$ \\
\hline Political & 174.71 & -.38 & -.49 & $-1.33^{*}$ \\
& $(527.06)$ & $(.42)$ & $(1.24)$ & $(.57)$ \\
\hline Employed & -2120.25 & -1.60 & 1.92 & .98 \\
& $(1686.98)$ & $(1.46)$ & $(3.97)$ & $(1.83)$ \\
\hline Major & -615.70 & $11.74 * *$ & -7.28 & -3.14 \\
& $(4098.99)$ & $(3.76)$ & $(9.92)$ & $(4.56)$ \\
\hline & Model n.s. & Model $p<.05$ & Model n.s. & Model n.s. \\
\hline
\end{tabular}

Cronbach's Alpha for the six questions examined is less than .01. However, alpha for the questions regarding having a credit card in your name and having a budget is .20. These results are only generalizable to the students in the university from which the survey was taken. 


\section{DISCUSSION}

The overall results are promising. Finnish students have avoided the crisis of student loan debts that has been such a burden to their American counterparts. Finland's college students are financially inexperienced, like all college students globally, and need significant help on use of consumer credit and budgeting. To Finland's credit, gambling among students does not seem to be a significant issue.

How did Finland avoid a student loan crisis? First, the Finnish system of higher education is founded on the principle of equal opportunity. Finland found that working while in college reduces probability to graduate (Asplund, Abdelkarim, and Skalli, 2009). As a result, the goal in Finland (and Nordic Welfare States) has been equal opportunity for all students so tuition, entrance exams, course exams are all free (Kivinen \& Hedman, 2000). The grant system is extensive and excludes very few. Only 1\% of applicants were denied higher education grants (Kivinen \& Hedman, 2000).

Additionally, Finland realized that the costs of higher education are more than tuition and books. As a result, Finland's higher education grants include costs for housing and utilities (Kivinen \& Hedman, 2000). In addition, food and mass transit is also subsidized (Kivinen \& Hedman, 2000). Also, students can use free or nearly free communal health services (Kivinen \& Hedman, 2000).

Finnish students have a strong work ethic so little need or use for student loans. Most students work part time to avoid student loan debts (Asplund, Abdelkarim, and Skalli, 2009). In addition, the student loans are viewed as temporary, often expecting to pay the loans off before graduation.

Part of the issue is also cultural. Student loans not popular in Finland. Less than $42 \%$ of students took loans despite government programs to encourage loans (Asplund, Abdelkarim, and Skalli, 2009). Student loans are very unpopular especially for more wealthy students (Asplund, Abdelkarim, and Skalli, 2009).

Students in Finland also share in the responsibility of student loans. Finnish students are expected to negotiate terms with lenders. In Finland, student loan repayment has been standardized. Loan repayment begins two years after graduation, and the repayment period is twice the withdrawal period (Kivinen \& Hedman, 2000).

\section{IMPLICATIONS FOR FURTHER RESEARCH \& CONCLUSION}

The biggest limitation of this pilot study is that it examines one educational institution during one time-period. Future projects should include other higher education institutions in Finland. Future projects should expand to multiple campuses and extend to universities as well as universities of applied sciences to see if those different populations have different results.

Another limitation is the sample size. A larger sample size could result in more (statistically significant) detailed analysis of the sub-groups (gender, religion, indoctrination). In addition, a larger sample size could define majors into discipline areas (accounting, tourism, management, etc.) to see if any disciplines had different views. The same distinctions can be made with political affiliation, as the Finnish population is heavily fractured. Smaller political groups have too few members in the current sample to do a comparison. Finally, the conclusions are time bound, as attitudes are influenced by the economic/political/cultural climate, which are certainly in flux. Clearly, further research on this topic is warranted.

While positive, this pilot study demonstrates that college students need more information on the

financial skills they need for everyday life. Further research should identify what specific topics should be addressed in financial life skills courses. 


\section{REFERENCES}

Ahola, S., \& Kokko, A. (2001). Finding the best possible students: Student selection and its problems in the field of business. Journal of Higher Education Policy and Management, 23(2), 191-203.

Anckar, O. (2000). University education in a bilingual country: The case of Finland. Higher Education in Europe 25(4), 499-506.

Arcada University. (2018). About Arcada. Retrieved from http://www.arcada.fi/en/about-arcada/arcadauniversity-applied-sciences-0.

Asplund, R., Abdelkarim, O.D., \& Skalli, A. (2009). Student loans and the likelihood of graduation: Evidence from Finnish cohort data. Higher Education in Europe, 34(2), 243-255.

Bailey, W., \& Spicer, A. (2007). When does national identity matter? Convergence and divergence in international business ethics. Academy of Management Journal, 50(6), 1462-1480.

Barbash, I., \& Taylor, L. (1997). Cross-cultural Filmmaking. Berkeley and Los Angeles, California: University of California Press.

Block, K. (2009). As card rules change, college students can still build a credit history. USA Today, 3b.

Carroll, A.B. (1999). Corporate social responsibility: Evolution of a definitional construct. Business and Society, 38(3), 268-295.

Chen, H., \& Volpe, R. P. (2002). Gender differences in personal financial literacy among college students. Financial Services Review, 11, 289-307.

Chu, K. (2009). Credit card fees keep going up. USA Today, $1 \mathrm{~b}$.

Clarke, K. (2005). Critical, multicultural education for remembering and reconciliation: A discussion of an interdisciplinary social science course for international students in Finland. Compare, 35(4), 479-494.

Craig, C.S., \& Douglas, S.P. (2006). Beyond national culture: Implication of cultural dynamics for consumer research. International Marketing Review, 26(3), 322-342.

Davenport, K. (2000). Corporate citizenship: A stakeholder approach for defining corporate social performance and identifying measures for assessing it. Business and Society, 39(2), 210-219.

Deegan, C., Rankin, M., \& Voght, P. (2000). Firms disclosure reactions to major social incidents: Australian evidence. Accounting Forum, 24(1), 101-130.

DiMaggio, P., \& Powell, W. (1983). The Iran cage revisited: Institutional isomorphism and collective rationality in organizational fields. American Sociological Review, 42, 113-123.

Drazin, R., Glynn, M.A., and Kazanjian, R.K. (1999). Multilevel theorizing about creativity in organizations: A sensemaking perspective. Academy of Management Review 24, 286-307.

Fey, C.F., \& Denison, D.R. (2003). Organizational culture and effectiveness: Can American theory be applied in Russia? Organizational Science, 14(6), 686-706.

Freeman, R.E. (1984). Strategic Management: A Stakeholder Approach. Massachusetts: Pitman Publishing.

Gambling in Finland today. (2018). Retrieved from https://www.onlinegamling.com/local/finland/

Goldman, G., Bounds, M., Bula, P., \& Fudalinski, J. (2012). On the ethical conduct of business organizations: A comparison of South African and Polish business management students. African Journal of Business Ethics, 6(1), 75-87.

Graduate students and credit cards fall 2006: An analysis of usage rates and trends. (2007). Retrieved from http://www.nelliemae.com/library/research.html.

Grunbaum, L. (1997). Attitudes of future managers towards business ethics: A comparison of Finnish and American business students. Journal of Business Ethics 16, 451-463.

Habisch, A., Patelli, L., Pedrini, M., and Schwartz, C. (2011). Different talks with different folks: A comparative survey of stakeholder dialog in Germany, Italy, and the U.S. Journal of Business Ethics, 100, 381-404.

Hodson, R., \& Dwyer, R. (2014). Millennials and Money: The Impact of Debt on young adults' financial life transitions. Denver CO: National Endowment of Financial Education. 
Huhtala, M., Kangas, M., Lamsa, A.M., \& Feldt, T. (2013). Ethical managers in ethical organizations? The leadership-culture connection among Finnish managers. Leadership \& Organization Development Journal, 34(3), 250-270.

Jauhiainen, A., Nori, H., and Alho-Malmelin, M. (2007). Various portraits of Finnish open university students. Scandinavian Journal of Educational Research, 51(1), 23-39.

Jones, J. E. (2005). College students' knowledge and use of credit. Financial Counseling and Planning, 16(2), 9-16.

Karekallas, M., Raento, P., \& Renkonen, T. (2014). Diffusion and learning: Twenty years of sports betting culture in Finland. UNLV Gaming Research \& Review Journal, 18(1), 25-40.

Kivinen, O., \& Hedman, J. (2000). From a loan-based to a grant-based student support system: The Finnish experience. European Journal of Education, 35(1), 97-19.

Koivukangas, O. (2005). Finland, Russia, and the European Union: the challenges of migration movements. AEMI Conference 2003.

Kujala, J. (2001). A multidimensional approach to Finnish managers' moral decision making. Journal of Business Ethics, 34, 231-254.

Kujala, J. (2010). Corporate responsibility perceptions in change: Finnish managers' views on stakeholder issues from 1994 to 2004. Business Ethics: A European Journal, 19(1), 14-34.

Kujala, J., Lamsa, A.M., \& Penttila, K. (2011). Managers' moral decision-making patterns over time: A multidimensional approach. Journal of Business Ethics, 100, 191-207.

Lahtinen, I. (1993). Suomen opintotukijarjestelman kehitys ja toimivuus. Sosiaalipolitiikan paivat 2223.10.1993 Tallinna.

Lamsa, A., Vehkapera, M., Puttonen, T., \& Pesonen, H. (2008). Effects of business education on women and men students' attitudes on corporate responsibility in society. Journal of Business Ethics, 82, 45-58.

Lamsa, A., \& Takala, T. (2000). Downsizing and ethics of personnel dismissals - the case of Finnish managers. Journal of Business Ethics, 23, 389-399.

Lopez-Navarro, M.A., \& Cipres, M.S. (2015). Social issues in business education: A study of students' attitudes. Journal of Education for Business, 90, 314-321.

Ludlum, M., Hongell, L., \& Tigerstedt, C. (2013). Finnish business students and business ethics: A preliminary survey. International Journal of Business and Social Science, 4(4), 120-127.

Ludlum, M., \& Smith, B.C. (2011). Assessing business in hindsight. Mustang Journal of Accounting \& Finance, 1, 104-116.

Ludlum, M., \& Smith, B.C. (2010). The credit card plague on the American college campus: A survey. Mustang Journal of Law \& Legal Studies, 1, 72-76.

Ludlum, M., Tilker, K., Ritter, D., Cowart, T., Xu, W., \& Smith, B.C. (2012). Financial Literacy and Credit Cards: A Multi Campus Survey. International Journal of Business and Social Science, 3(7), 25-33. Retrieved from www.ijbssnet.com

Maksimainen, J., Saariluoma, P., \& Jokivuori, P. (2010). Corporate social responsibility and values in innovation management. Journal of Social Sciences, 5(2), 97-101.

McCabe, D.L., Dukerich, J.M., \& Dutton, J.E. (1991). Context, values and moral dilemmas: Comparing the choices of business and law school students. Journal of Business Ethics, 10, 951-960.

Nieman, G., and Bennett, A. (2006). Business Management: A Value Chain Approach. Pretoria: Van Schaik.

Niemi, P.M., Kuusisto, A., \& Kallioniemi, A. (2014). Discussing school celebrations from an intercultural perspective - a study in the Finnish context. Intercultural Education, 25(4), 255-268.

Norvilitis, J.M., Merwin, M.M., Osberg, T.M., Roehling, P.V., Young, P., \& Kamas, M.M. (2006). Personality factors, money attributes, financial knowledge, and credit-card debt in college students. Journal of Applied Social Psychology, 36(6), 1395-1413.

Post, J.E., Preston, L.E., and Sachs, S. (2002). Managing the extended enterprise: The new stakeholder view. California Management Review 45(1), 6-28. 
Purhonen, A. (1995). Ei tassa uskalla ottaa opintolainaa, kireeta on jo muutenkin. Aiheira 9/1995. Stakes.

Riivari, E., \& Lamsa, A.M. (2014). Does it pay to be ethical" Examining the relationship between organizations' ethical culture and innovativeness. Journal of Business Ethics, 124, 1-17.

Robb, C.A., \& Sharpe, D.L. (2009). Effect of personal financial knowledge on college students' credit card behavior. Journal of Financial Counseling and Planning, 20(1), 25-43.

Samuelson, T.D. (2010). New credit card laws 2010: How will I benefit? Christian Science Monitor, 29.

Shauki, E. (2011). Perceptions on corporate social responsibility: A study in capturing public confidence. Corporate Social Responsibility and Environmental Management, 18, 200-208.

Statistics Finland. (2018). https://www.stat.fi/tup/suoluk/index_en.html.

U.S. Department of Treasury. (2008). Financial Literacy and Education Commission. Retrieved from www.mymoney.gov

Vogelaar, H. (2013). An intriguing ecumenical dialogue: Lutheran-Orthodox encounters in Finland. Exchange, 42, 267-301.

Vuontisjarvi, T. (2006). Corporate social reporting in the European context and human resource disclosures: An analysis of Finnish companies. Journal of Business Ethics 69, 331-354.

Warwick, J., \& Mansfield, P. (2000). Credit card consumers: College students' knowledge and attitude. Journal of Consumer Marketing, 17(7), 617-626. 


\section{APPENDIX}

\section{Survey Questions}

This is a voluntary research project on student views of financial issues. The survey should take approx. five minutes to complete. There is no penalty for refusal to participate. You must be at least 18 years old to take this survey. DO NOT PUT YOUR NAME OR IDENTITY NUMBER ON THE SURVEY. ALL ANSWERS ARE ANONYMOUS AND CONFIDENTIAL. If you do not wish to participate, you may hand in the survey form blank. Thank you for your input on this research project.

What year in school are you presently?

First year Second year Third year Beyond third year

What is your major?

Are you male or female? Male Female

How would you describe your political views?

Centre Party (Suomen Kestusta)

Finns Party (Perussuomalaiset)

National Coalition (Kansallinen Kokoomus)

Socialist Democrat (Suomen Sosialidemokraattinen Puolue)

Left Alliance (Vasemmistoliitto) Swedish Party (Svenska Folkpartiet) Other

Are you currently employed (this semester)? No Part-time Full-time

Are you married? What is your age?

How many children do you have?

How many credit cards do you have?

How would you describe your religious views?

Lutheran Catholic Christian Hindu Jewish

Buddhist Muslim Not Religious

Do you have a credit card in your name?

What is the Interest Rate (APR) on the credit card you use most often?

I don't know I don't have any credit cards

What is the Late Fee for the credit card you use most often?

I don't know I don't have any credit cards

What is the Cash Advance Fee for the credit card you use most often?

I don't know I don't have any credit cards

What is the over balance fee for the credit card you use most often?

I don't know I don't have any credit cards

What is the current balance of the credit card you use most often?

I don't know I don't have any credit cards

How much do you expect to borrow in student loans by the time you complete your degree?

I will not have any student loans

What interest rate (APR) are you charged on your student loan balance?

I don't know I won't have any student loans

How many years after graduation do you expect it will take you to pay off your student loans?

Do you have a monthly budget?

What percentage of your monthly budget goes toward housing?

I don't know I don't have a monthly budget

What percentage of your monthly budget is used to pay credit card payments?

I don't know I don't have a monthly budget

How much per month do you spend for your cell phone?

How often do you eat in a restaurant per week?

What percentage of your monthly budget is spent on eating in restaurants?

I don't know I don't have a monthly budget

How many times a year do you visit a casino?

How much do you spend gambling per visit? 
How much do you owe in gambling debts?

Do you think you have a problem with gambling?

NOTE: There were additional questions not part of this research.

72 Journal of Higher Education Theory and Practice Vol. 19(4) 2019 